\title{
Peptide Nanofiber Scaffolds for Multipotent Stromal Cell Culturing
}

\section{Seher Ustun, Samet Kocabey, Mustafa 0. Guler, and Ayse B. Tekinay}

\begin{abstract}
Self-assembled peptide nanofibers are versatile materials providing suitable platforms for regenerative medicine applications. This chapter describes the use of peptide nanofibers as extracellular matrix mimetic scaffolds for two-dimensional (2D) and three-dimensional (3D) multipotent stromal cell culture systems and procedures for in vitro experiments using these scaffolds. Preparation of $2 \mathrm{D}$ and 3D peptide nanofiber scaffolds and cell culturing procedures are presented as part of in vitro experiments including cell adhesion, viability, and spreading analysis. Analysis of cellular differentiation on peptide nanofiber scaffolds is described through immunocytochemistry, qRT-PCR, and other biochemical experiments towards osteogenic and chondrogenic lineage.
\end{abstract}

Keywords: Peptide nanofibers, Self-assembly, Hydrogels, Multipotent stem cells, Nanofiber networks

\section{Introduction}

Multipotent stromal cells (MSCs) hold great potential for regenerative medicine applications due to their ease of isolation from bone marrow and other tissues such as adipose, periosteum, synovial membrane, and synovial fluid (1). These cells are more prone to generate particular tissue types such as cartilage, bone, and adipose, and have potential to escape from immune system (2). Due to these reasons, use of MSCs is highly preferable in regenerative medicine applications.

MSC fate decision can be fine-tuned by a number of signaling molecules residing in the microenvironment of these cells. The dynamic interactions of cell-cell, cell-extracellular matrix, and cell-soluble factors that take place in stem cell niche determine the differentiation patterns of stem cells. In regenerative medicine studies, artificial scaffolds are engineered by exploiting these interactions to mimic stem cell milieu. By this way engineered scaffold system on which MSCs reside provides control over cell fate. Therefore, 
mechanical, chemical, and biological signals incorporated within artificial scaffold systems must be precisely controlled in a spatiotemporal fashion (3).

Self-assembled peptide nanofibers are versatile nanostructures that can trigger and control cellular behaviors such as adhesion, proliferation, migration, and differentiation through functional epitopes. These nanofibers are usually composed of peptide molecules that have bioactive groups and $\beta$-sheet-forming peptide segments in addition to hydrophobic groups. Hydrophobic part of the peptide molecules triggers self-assembly process through hydrophobic collapse in water. Hydrogen bonding between the $\beta$-sheet-forming peptide segments induces formation of well-defined and long cylindrical fibers instead of spherical micelles. Self-assembly through charge screening can also be triggered by addition of charged amino acids in peptide sequence followed by mixing with oppositely charged peptides or electrolytes (4). Peptide nanofibers are versatile structures so that many bioactive peptide epitopes can be presented on the design in high density and this characteristic provides a variety of functional properties that can be utilized in nanotechnology and regenerative medicine applications. This characteristic is especially important for mimicking extracellular matrix components, which are highly important in regenerative medicine applications. Figure 1 illustrates the nanofiber formation through self-assembly of
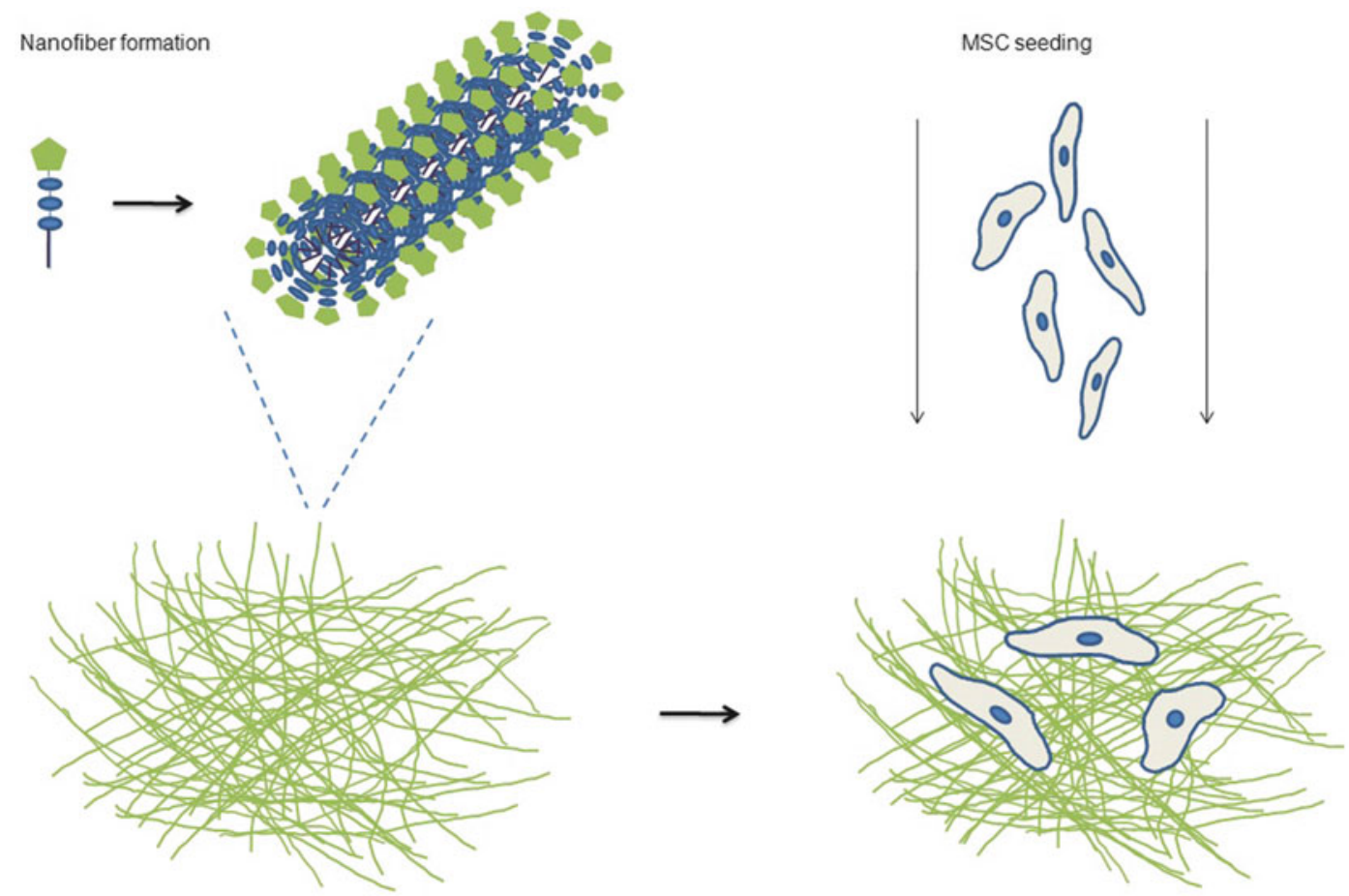

Fig. 1 Schematic representation of nanofiber formation through self-assembly and MSC seeding on the peptide nanofiber scaffolds 
monomers and MSC seeding on the scaffolds. So far, researchers have used a number of bioactive epitopes on the peptide nanofiber systems to alter cellular behaviors by mimicking functional ligands found in the extracellular matrix that interact with cell surface components, such as growth factor receptors, integrins, and glycosaminoglycans. For example, cellular adhesion can be triggered through commonly used peptide ligands such as RGDS (5), REDV (6), or KRSR (7) and differentiation can be induced by IKVAV (8) epitope for neural cells and DGEA (9) for osteogenesis.

In this chapter, we describe protocols used to develop 2D and 3D self-assembled peptide nanofiber scaffolds and their use for MSC culture and differentiation in detail. Specifically, MSC culturing on 2D and 3D peptide nanofibers including analysis of cellular characteristics such as adhesion, spreading, viability, and differentiation by using immunocytochemistry, qRT-PCR, and osteogenic or chondrogenic specific biochemical assays is discussed (see Note 1).

\section{Materials}

Materials used in peptide synthesis, purification, and characterization were previously described (6-8).

\subsection{Cell Culture}

1. Pipettes and tissue culture plates (Corning).

2. $1 \times$ PBS.

3. Expansion medium: Dulbecco's Modified Eagle's MediumGlutamax, Low (1.5 g/L) Glucose (Invitrogen) supplemented with $10 \%$ MSC qualified FBS and 1\% penicillin-streptomycin (Invitrogen).

4. $0.25 \%$ Trypsin-EDTA (Invitrogen).

5. Osteogenic differentiation medium: Dulbecco's Modified Eagle's Medium-Glutamax, Low (1.5 g/L) Glucose (Invitrogen) supplemented with $10 \%$ MSC qualified FBS and $1 \%$ penicillin-streptomycin (Invitrogen), $10 \mathrm{mM} \beta$-glycerophosphate (Alfa Aesar), $50 \mu \mathrm{g} / \mathrm{mL}$ L-ascorbic acid (Alfa Aesar), and $10 \mathrm{nM}$ dexamethasone (Sigma).

6. Chondrogenic differentiation medium: Dulbecco's Modified Eagle's Medium, High ( $4.5 \mathrm{~g} / \mathrm{L})$ Glucose (Invitrogen) supplemented with $10 \mathrm{ng} / \mathrm{mL}$ TGF- $\beta 1$ (Invitrogen), $1 \times 10^{-7} \mathrm{M}$ dexamethasone (Sigma), $100 \mu \mathrm{M}$ L-ascorbic acid (Alfa Aesar), $1 \%$ sodium pyruvate (Invitrogen), $0.5 \mathrm{mg} / \mathrm{mL} \mathrm{BSA,} 10 \mu \mathrm{g} / \mathrm{mL}$ insulin, $6 \mu \mathrm{g} / \mathrm{mL}$ transferrin, and $3 \times 10^{-8} \mathrm{M}$ sodium selenite. 


\subsection{Adhesion, Spreading, Viability, and Proliferation}

2.3 ALP Activity

\subsection{Alizarin Red Staining}

\subsection{Papain Digestion}

\subsection{Dimethylmet- hylene Blue Assay}

1. Adhesion medium: Dulbecco's Eagle modified medium with Low (1.5 g/L) Glucose supplemented with $4 \mathrm{mg} / \mathrm{mL}$ BSA (Invitrogen), $50 \mu \mathrm{g} / \mathrm{mL}$ cyclohexamide (AppliChem), and 1\% penicillin-streptomycin.

2. FITC-conjugated phalloidin (Sigma).

3. $2 \%$ glutaraldehyde (Sigma) and $4 \%$ osmium tetroxide (Sigma).

4. Increasing concentrations of EtOH.

5. Calcein AM (Invitrogen) diluted to $1 \mu \mathrm{M}$ in PBS.

1. M-PER Protein Extraction Solution (Thermo)

2. Protease inhibitor cocktail

3. BCA Protein Assay Kit (Thermo)

4. $\mathrm{NaOH}(0.25 \mathrm{M})$

5. $p$-nitrophenol (Sigma)

6. $p$-nitrophenylphosphate substrate solution (Sigma)

1. Alizarin Red-S solution: Prepare $40 \mathrm{mM}$ Alizarin Red-S solution by dissolving appropriate amount of Alizarin Red-S (Sigma) in $\mathrm{ddH}_{2} \mathrm{O}$ and adjust $\mathrm{pH}$ to 4.2 by titrating with $1 \mathrm{M} \mathrm{NH}_{4} \mathrm{OH}$.

2. Ethanol (70\%).

3. Cetylpyridinium chloride (CPC) solution: Prepare $10 \%(\mathrm{w} / \mathrm{v})$ CPC solution by dissolving appropriate amount of CPC (Merck) in $\mathrm{Na}_{3} \mathrm{PO}_{4}$ buffer $(10 \mathrm{mM}, \mathrm{pH} 7)$.

1. PBE buffer: First prepare $100 \mathrm{~mL} 500 \mathrm{mM} \mathrm{Na}{ }_{2}$ EDTA by

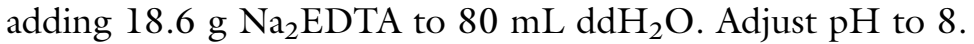
Then prepare $100 \mathrm{mM}$ sodium phosphate buffer by dissolving $6.53 \mathrm{~g} \mathrm{Na}_{2} \mathrm{HPO}_{4}$ and $6.48 \mathrm{~g} \mathrm{NaH}_{2} \mathrm{PO}_{4}$ in $900 \mathrm{~mL}$ and add $10 \mathrm{~mL}$ of $500 \mathrm{mM} \mathrm{Na} 2 \mathrm{EDTA}$. Adjust $\mathrm{pH}$ to 6.5 , and then complete volume to $1 \mathrm{~L}$. Sterilize with $0.22 \mu \mathrm{m}$ filter.

2. Papain digestion buffer: Prepare first $10 \mathrm{mM} \mathrm{L}$-cysteine solution by dissolving $47.25 \mathrm{mg} \mathrm{L}$-cysteine hyrdrochloride in $30 \mathrm{~mL}$ PBE buffer. Then transfer $20 \mathrm{~mL}$ of PBE-cysteine solution to a sterile tube and add papain (Sigma) to get $125 \mu \mathrm{g} / \mathrm{mL}$ concentration of papain solution (see Note 2 ).

1. 1 L DMB solution: Prepare $40 \mathrm{mM}$ Glycine (Sigma), $40 \mathrm{mM}$ $\mathrm{NaCl}$ by dissolving $2.37 \mathrm{~g} \mathrm{NaCl}$ and $3.04 \mathrm{~g}$ glycine in $900 \mathrm{~mL}$ $\mathrm{ddH}_{2} \mathrm{O}$. Then dissolve $16 \mathrm{mg}$ dimethylmethylene blue (DMMB) (Sigma) in $5 \mathrm{~mL}$ absolute EtOH for $16 \mathrm{~h}$ with a magnetic stir bar. Add dissolved DMMB to $\mathrm{NaCl}$-glycine solution. Then adjust $\mathrm{pH}$ to 3 . Complete to $\mathrm{I} \mathrm{L}$ with $\mathrm{ddH}_{2} \mathrm{O}$. Then sterilize with $0.22 \mu \mathrm{m}$ filter (see Note 3 ).

2. Papain digests.

3. Chondroitin sulfate salt standard solutions. 
2.7 RNA Isolation and $q R T-P C R$

2.8 Immunocytochemistry

2.9 Fixation, Dehydration, Embedding, and Sectioning of 3D Cultures
RNA Isolation:

1. Trizol Reagent (Invitrogen)

2. DNAse/RNase free water (Gibco)

3. DNAse/RNase free Eppendorf tubes

4. Temperature-controlled centrifuge

5. RNase-free solvents: Chloroform, isopropanol, and increasing concentrations of $\mathrm{EtOH}$

qRT-PCR:

1. SuperScript $\left.{ }^{(}\right)$III Platinum ${ }^{\circledR}$ SYBR $\left.^{(}\right)$Green One-Step qRT-PCR Kit (Invitrogen)

2. PCR thermal cycler (Bio-Rad)

3. Quick spin

4. Vortex

5. RNA samples

1. $1 \times$ PBS

2. Fixative; $4 \%$ paraformaldehyde/PBS

3. Blocking solution: $1 \%$ BSA-PBS

4. $0.1 \%$ Triton X-100

5. Prolong Gold antifade reagent (Invitrogen)

1. Fixative; $4 \%$ paraformaldehyde/PBS

2. Coverslips

3. Glass slides

4. Xylene (Sigma)

5. Graded EtOH: 70, 80, 95, 100\%

6. Paraffin

7. Embedding cassettes

8. Embedding molds

9. Microtome (Leica SM 2010 R)

10. Hybridization oven

\section{Methods}

\subsection{Peptide}

Synthesis,

Purification, and Characterization
Peptide synthesis is performed by using a standard Fmoc-protected solid-phase peptide synthesis method. Purification and characterization steps are carried out as described previously (6-8). Alternative peptide synthesis protocols can be accessed from here (10).

1. After collection of peptide from high-performance liquid chromatography (HPLC) purification, remove the organic solvent 


\subsection{Cell Culture}

3.2.1 Cell Culture on $2 D$ Scaffold by using rotary evaporator. Then, freeze the peptide samples at $80^{\circ} \mathrm{C}$ for $4-5 \mathrm{~h}$ and lyophilize to obtain peptide powder.

2. Dissolve lyophilized peptide samples in ultrapure water. In order to completely dissolve peptide samples, add appropriate amount of $\mathrm{HCl}$ or $\mathrm{NaOH}$ according to the $\mathrm{pKa}$ values of peptides. Sonication might be required to prevent the small peptide aggregate formations in the solution by using ultrasonicator.

3. Carry out circular dichroism (CD) experiment to reveal the secondary structure of peptides. Dissolve peptides in ultrapure water at $10^{-5} \mathrm{M}$ concentration separately. (Peptide concentrations can be prepared in the range of $1 \times 10^{-6}$ and $\left.5 \times 10^{-4}\right)$. The details of the measurement procedure can be found here $(6-8,11)$. Analysis of the secondary structure of peptide nanofibers is important for determining the effects of structural properties of the nanofiber system on the cells.

4. In order to analyze mechanical characteristics of peptide nanofiber hydrogel system, perform rheology experiments by using a rheometer. According to the plate diameter and gap size, mix peptides in a way that the gap is full with peptide mixture and wait for gelation for $10 \mathrm{~min}$. Then, perform the analysis by using various measurements depending on the purpose, such as frequency sweep or time-dependent measurements. Gel formation is described with the equation $\mathrm{G}^{\prime}>\mathrm{G}^{\prime \prime}$. Further details can be found here $(6-8,11)$.

5. Characterize self-assembled peptide nanofibers and their network formation by using various microscopy techniques such as scanning electron microscopy (SEM) and transmission electron microscopy (TEM) as described here (12).

6. After characterizing the peptide molecules and self-assembled peptide nanofibers, cell culture experiments on peptide nanofibers are performed.

Self-assembly of two oppositely charged peptide molecules at neutral $\mathrm{pH}$ has been previously defined (13). Peptide gels have the ability to mimic the native extracellular matrix due to their nanofibrous structure and hydrogel characteristics. In order to construct 2D scaffolds for MSC culturing applications, negatively charged peptides and positively charged peptides are used to form gels on tissue culture plates. Figure 2 illustrates gel formation and sterilization steps before cell seeding.

1. Dissolve the peptides in water to obtain $0.1 \mathrm{mM}$ peptide solution and adjust $\mathrm{pH}$ to 7.4 using $1 \mathrm{mM} \mathrm{HCl}$ or $\mathrm{NaOH}$, depending on the sequence and the $\mathrm{p} K \mathrm{a}$ of peptide (see Note 4 ).

2. Sonicate peptide solutions in ultrasound bath for 10-30 min, depending on the volume of your peptide solution. 


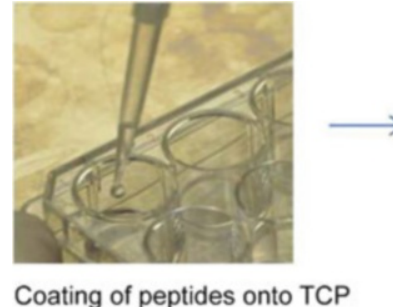

Coating of peptides onto TCP

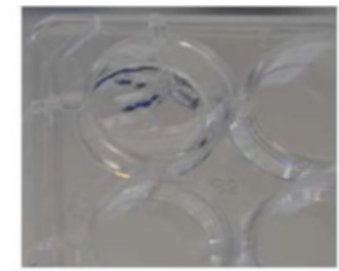

Gel formation after mixing of two peptide solutions

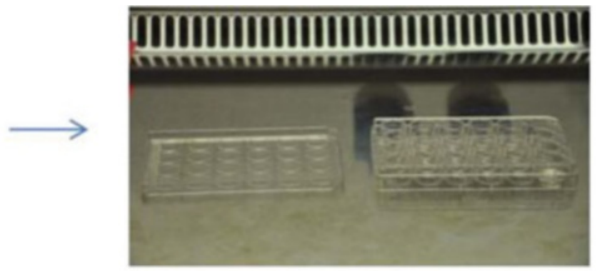

Slow solvent evaporation under flow hood and sterilization under UV lamp

Fig. 2 Steps of 2D scaffold preparation before cell culture. Left. Peptide solutions are added one by one. Middle: After mixing gel formation immediately occurs. Right. Peptide gels are kept in fume hood for drying overnight and sterilized under UV afterwards

3.2.2 Cell Culture

on 3D Scaffold
3. Add negatively and positively charged peptide solutions at a final concentration of $200 \mu \mathrm{L} / \mathrm{cm}^{2}$. After adding the first peptide solution, drip second peptide solution onto the first one and stir for mixing.

4. Incubate at $37^{\circ} \mathrm{C}$ for $30 \mathrm{~min}$.

5 . To get $2 \mathrm{D}$ coating, leave gels under laminar flow hood overnight in order to evaporate the solvent.

6. Sterilize coated plates under UV lamp for $30 \mathrm{~min}$ to $1 \mathrm{~h}$. After sterilization, keep coated plates sterile.

7. Prepare MSC suspension in expansion medium.

8. Seed $500 \mu \mathrm{L}$ of cell suspensions onto each coating. In order to distribute cells homogeneously gently tap well plate. Place the plates in a $37^{\circ} \mathrm{C}$ humidified incubator with $5 \% \mathrm{CO}_{2}$. Change media every 3-4 days until the date of analysis.

1. Dissolve peptides in HEPES buffer to obtain $10 \mathrm{mM}$ peptide solution (see Note 5 ).

2. Sonicate peptide solutions in ultrasound bath for $10-30 \mathrm{~min}$, depending on the volume of your peptide solution.

3. Sterilize peptide solutions under UV lamp for $30 \mathrm{~min}$ to $1 \mathrm{~h}$. After sterilization keep peptide solutions sterile.

4. Prepare MSC suspension at $2 \times 10^{4}$ cells $/ \mu \mathrm{L}$ concentration in differentiation medium.

5. Place coverslips into each well of 24-well plate.

6. Add the first peptide solution onto coverslip.

7. Add $10-20 \mu \mathrm{L}$ of cell solution onto first peptide solution by mixing slightly. Be careful not to disturb the convex shape of peptide solution drop while adding cell suspension.

8. Then add the second peptide solution onto the mixture of cell and first peptide solution. Be careful not to disturb the convex shape of the cell-first peptide mixture while adding the second peptide solution. This method is called the sandwich method 
3.2.3 Fixation,

Dehydration, Embedding, and Sectioning of $3 D$ Cultures and provides a powerful tool, especially if you would like to analyze the migration or spreading patterns of cells.

Alternatively, you can first mix the first peptide solution with cell suspension in an Eppendorf tube prior to placing the mixture in wells. Then place the mixture onto coverslip and add the second peptide solution onto that. Be careful not to disturb the convex shape of mixture. This method results in a more homogenous cell-scaffold mixture.

9. Incubate gel at $37^{\circ} \mathrm{C}$ for $30 \mathrm{~min}$.

10. Add $750 \mu \mathrm{L}$ of culture medium onto gel carefully. Change culture medium every other day.

11. The cells should be cultured for at least 3 weeks.

1. At determined time points remove the medium from the $3 \mathrm{D}$ cultures and wash with $1 \times$ PBS, taking care not to disturb constructs.

2. Fix $3 \mathrm{D}$ constructs in $4 \%$ paraformaldehyde for $24-36 \mathrm{~h}$ in the same culture plates.

3. Then first aspirate out paraformaldehyde, dehydrate samples in graded EtOH solutions, and clear them in xylene as follows:

(a) $70 \%$ EtOH-two changes- 1 h each

(b) $80 \% \mathrm{EtOH}$-two changes - $\mathrm{l}$ h each

(c) $95 \% \mathrm{EtOH}$ - two changes- 1 h each

(d) $100 \%$ EtOH-two changes - 1 h each

(e) Xylene-two changes- $1 \mathrm{~h}$ each

4. Place embedding cassettes into molds and label them.

5. Place 3D constructs onto embedding cassettes and pour warm paraffin gently. Use forceps to hold the glass coverslips that 3D constructs are placed on while transferring them (see Note 6).

6. Cool paraffin blocks at RT for $30 \mathrm{~min}$ to $1 \mathrm{~h}$, and then trim and place blocks to microtome.

7. Cut $5 \mu \mathrm{m}$ sections of paraffin-embedded constructs using microtome. Transfer paraffin ribbon to water bath at $40^{\circ} \mathrm{C}$ for 2-3 s. Take sections on glass slides.

8. Leave slides at RT to dry and then bake them in $45-50^{\circ} \mathrm{C}$ oven overnight.

9. Deparaffinize and rehydrate sections in graded EtOH solutions as follows:

(a) Xylene-2 changes-10 min each

(b) $100 \%$ EtOH-two changes - 3 min each

(c) $95 \% \mathrm{EtOH}-1 \mathrm{~min}$

(d) $80 \% \mathrm{EtOH}-1 \mathrm{~min}$

10. Then rinse in distilled water. 

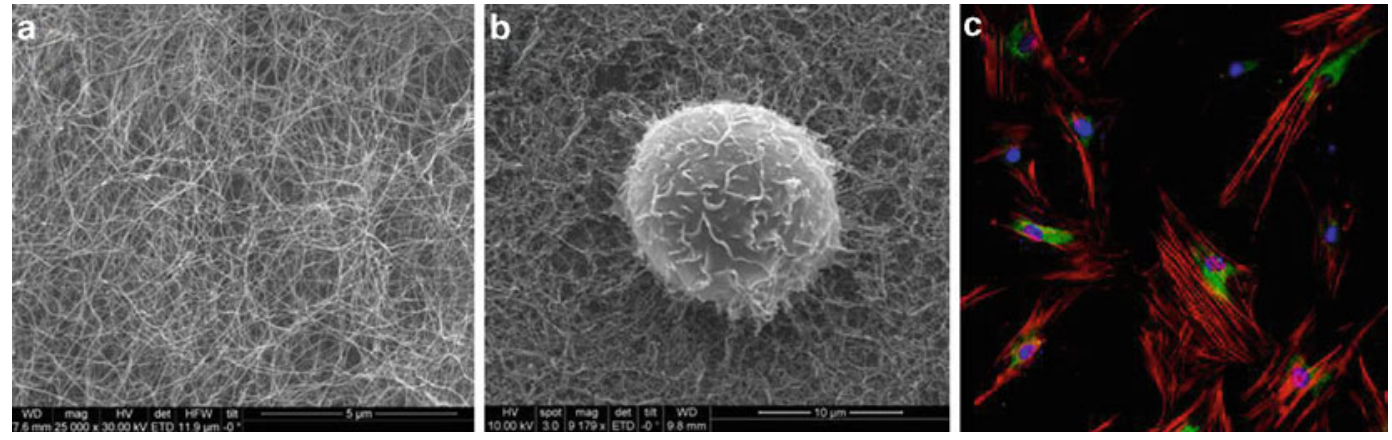

Fig. 3 ECM-mimetic peptide nanonetwork provides mechanical support to the MSCs in addition to bioactive cues presented by the nanofibers. (a) Peptide nanofiber scaffold imaged by SEM. (b) After 2-h seeding of cells, cells start to adhere on scaffold and extend their protrusions. (c) After $24 \mathrm{~h}$, cells spread and gain their native morphology (Red : actin filaments; green: CD44, a stem cell marker; blue : cell nuclei)

\subsection{Biological Characterizations}

\subsubsection{Cell Adhesion Tests}

1. Prior to the experiment, replace the medium of stem cells in the flask with serum-free DMEM supplemented with $4 \mathrm{mg} / \mathrm{mL}$ BSA and $50 \mu \mathrm{g} / \mathrm{mL}$ cyclohexamide for $\mathrm{l} \mathrm{h}$ at standard cell culture conditions $\left(37^{\circ} \mathrm{C}\right.$ humidified chamber with $\left.5 \% \mathrm{CO}_{2}\right)$.

2. After trypsinization and resuspension of cells in serum-free medium, count the cell number with hemocytometer.

3. Seed cells on peptide nanofiber-coated surfaces at $5 \times 10^{4}$ cells $/ \mathrm{cm}^{2}$ density.

4. After $1-\mathrm{h}$ incubation remove medium containing unbound cells and wash the wells twice with PBS.

5. Add $200 \mu \mathrm{L}$ of $2 \mu \mathrm{M}$ calcein AM in PBS per well and incubate cells for $30 \mathrm{~min}$ at standard culture conditions.

6. After incubation, take images of stained cells from at least five random points per well by using fluorescence microscope.

7. Count adhered cells using Image $\mathrm{J}$ and normalize data to polystyrene tissue culture plate surface.

3.3.2 Spreading

One of the early cellular responses upon seeding on a material is cell spreading. In order to monitor spreading characteristics of MSCs after seeding on scaffold systems, cells are stained with TRITCconjugated phalloidin dye that binds to F-actin stoichiometrically. Moreover, spreading characteristics of cells are also analyzed via SEM imaging. Figure 3 illustrates the adhesion and spreading of cells that are cultured on peptide nanofiber scaffolds.

1. For phalloidin staining, remove medium from cultures 3 and $48 \mathrm{~h}$ after seeding cells, and wash wells with $\mathrm{l} \times \mathrm{PBS}$.

2. Fix cells in $4 \%$ paraformaldehyde/PBS for $10 \mathrm{~min}$ at room temperature, and then wash extensively with $1 \times$ PBS. 
3.3.3 Viability

\subsection{Differentiation Studies}

\subsubsection{Osteogenic} Differentiation

ALP Activity
3. In order to permeabilize cells, treat cells with $0.1 \%$ Triton $\mathrm{X}-100$ in PBS, and wash again with PBS.

4. Stain cells with $50 \mu \mathrm{g} / \mathrm{mL}$ phalloidin solution/PBS for $20 \mathrm{~min}$ and wash with PBS extensively.

5. Mount cover glasses with Prolong Gold Antifade Reagent (Invitrogen), seal with nail polish, and then analyze.

6. For SEM imaging, after 3 and 48 h of incubation, remove the medium from cultures and wash cells with $1 \times$ PBS.

7. Fix attached cells with $2 \%$ glutaraldehyde/PBS solution for $2 \mathrm{~h}$ and wash with $1 \times$ PBS briefly.

8. Then treat fixed cells with $4 \%$ osmium tetroxide for $30 \mathrm{~min}$ and wash briefly with $1 \times$ PBS.

9. Dehydrate cells in graded $\mathrm{EtOH}$ solutions starting with $20 \%$ and continuing up to absolute EtOH for $10 \mathrm{~min}$ at each step.

10. Dry samples using critical point dryer.

11. Coat samples with $6 \mathrm{~nm} \mathrm{Au} / \mathrm{Pd}$ using a sputter coater.

12. Analyze samples under scanning electron microscope and take images by using an ETD detector at high vacuum mode at $10 \mathrm{keV}$ beam energy.

Viability of cells on scaffolds is determined using calcein AM staining. Calcein is a membrane-permeable dye. When it enters the cells, intracellular esterases cleave the acetoxymethyl (AM) ester group resulting in the membrane-impermeable calcein fluorescent dye. Dead cells cannot retain calcein dye due to their impaired membrane integrity.

1. On days 1, 2, and 3, remove medium from the cultures and wash wells with PBS in order to remove dead cells.

2. Add $200 \mu \mathrm{L}$ of $2 \mu \mathrm{M}$ calcein AM per well and incubate cells for $30 \mathrm{~min}$ at standard culture conditions.

3. After incubation, take images of viable cells from at least five random points per well by using fluorescence microscope.

4. Count viable cells using Image J and normalize data to polystyrene tissue culture plate surface.

Seed MSCs in growth medium (DMEM-Glutamax/10\% FBS/1\% penicillin) to the peptide nanofiber-coated wells at $10^{4}$ cells $/ \mathrm{cm}^{2}$ ratio. After reaching confluency (1-2 days), exchange growth medium with osteogenic medium as described in Section 2.

Alkaline phosphatase (ALP) is an enzyme that hydrolyzes inorganic pyrophosphate to provide inorganic phosphate source and its activity is used as an early marker of osteogenic differentiation. 
1. At predetermined time intervals $(3,7,10,14,21$, and 28 days $)$ remove the osteogenic medium from wells.

2. Wash with $1 \times$ PBS once.

3. Add $100 \mu \mathrm{L}$ of protein extraction solution to each well and incubate on shaker for $30 \mathrm{~min}$ at room temperature.

4. Collect the protein from each well and transfer them into chilled $1.5 \mathrm{~mL}$ sterile Eppendorf tubes. Pipetting and scratching the surfaces could be beneficial to gather proteins efficiently.

5. Centrifuge the tubes at $14,000 \times g$ for $10 \mathrm{~min}$ at $4^{\circ} \mathrm{C}$.

6. Transfer the supernatants (including proteins) from each tube into clean chilled tubes. Take care not to take pellet, which is composed of cellular debris.

7. Perform protein assay in 96-well plates in order to measure protein concentration of each sample by using protein assay kit.

8. Prepare $p$-nitrophenol standards by serial dilution with $0.25 \mathrm{M}$ $\mathrm{NaOH}$. Use $0.25 \mathrm{M} \mathrm{NaOH}$ alone for blank.

9. Add $50 \mu \mathrm{L}$ of protein solution for each sample to the wells of 96-well plate. Bring the total volume up to $200 \mu \mathrm{L}$ by adding $150 \mu \mathrm{L} p$-nitrophenylphosphate substrate solution.

10. After incubating for $30 \mathrm{~min}$ on shaker at RT, measure absorbance at $405 \mathrm{~nm}$ by using microplate reader.

Alizarin Red-S staining is used to determine calcium deposition and mineralization of cells through binding of Alizarin Red-S to calcium ions.

1. At predetermined time points $(7,14,21$, and 28 days $)$ discard osteogenic medium from the wells.

2. Wash the cells with $1 \times$ PBS once.

3. Add $200 \mu \mathrm{L}$ of ice-cold ethanol (70\%) to each well and incubate them for $\mathrm{l} h$ at room temperature.

4. Wash with $\mathrm{ddH}_{2} \mathrm{O}$ twice (5-10 $\left.\mathrm{min}\right)$.

5. Add $200 \mu \mathrm{L}$ of Alizarin Red-S solution on top of the cells and incubate them on shaker for $30 \mathrm{~min}$ at room temperature.

6. Wash with $\mathrm{ddH}_{2} \mathrm{O}$ four to five times to get rid of nonspecific Alizarin Red-S binding.

7. Add enough PBS to cover wells and use optical microscope for imaging.

8. Discard PBS and add $200 \mu \mathrm{L}$ CPC solution to extract Alizarin Red-S $/ \mathrm{Ca}^{2+}$ complex from the surface by incubating on shaker for $30 \mathrm{~min}$.

9. Measure absorbance at $562 \mathrm{~nm}$ by using microplate reader. 
RNA Isolation and qRT-PCR

RNA Isolation
All tubes and tips should be RNase free and RNA isolation is performed under Class I airflow hood.

1. At least $1.5 \times 10^{5}$ cells are required for sufficient RNA isolation per experimental group.

2. Remove the medium from the wells and wash briefly with PBS.

3. Add $500 \mu \mathrm{L}$ Trizol reagent on cells, mix extensively, and then transfer cell lysates into $2 \mathrm{~mL}$ RNase-free Eppendorf tubes. At this step, cell lysates could be stored in a $-80^{\circ} \mathrm{C}$ freezer.

4. Add $300 \mu \mathrm{L}$ of chloroform onto cell lysates, shake tubes vigorously to dissolve lipids, and leave at RT for 2-3 min.

5. Centrifuge samples at $15,000 \mathrm{rpm}$ for $15 \mathrm{~min}$ at $4^{\circ} \mathrm{C}$. Transfer 600-700 $\mu \mathrm{L}$ of upper clear phase into a clean tube. Be careful not to disturb bottom layer; otherwise RNA will be contaminated by DNA and phenol extracts.

6. Add equal volume of isopropanol to the clear solution and mix. Incubate for $10 \mathrm{~min}$ at RT. In order to increase RNA yield you can incubate samples at $-20^{\circ} \mathrm{C}$.

7. Centrifuge samples in order to precipitate RNA at $15,000 \mathrm{rpm}$ for $12 \mathrm{~min}$ at $4^{\circ} \mathrm{C}$.

8. After centrifugation discard supernatant. Add $1 \mathrm{~mL}$ of $70 \%$ EtOH. Be careful not to dissolve the pellet; just detach it from the tube wall.

9. Centrifuge samples at $8,000 \mathrm{rpm}$ for $8 \mathrm{~min}$ at $4^{\circ} \mathrm{C}$.

10. Discard all supernatant and air-dry the pellet until there is no EtOH left. Add $30 \mu \mathrm{L}$ DNase/RNase-free water and dissolve the pellet.

11. Assess yield and purity of RNA using NanoDrop.

qRT-PCR

Osteogenic and chondrogenic differentiation are indexed by analysis of bone- or cartilage-specific gene expression, respectively. For gene expression analysis, comparative Ct method with primer efficiency correction is used.

1. The cDNA synthesis from RNA and qRT-PCR reactions are performed using SuperScript ${ }^{\circledR}$ III Platinum ${ }^{(}$SYBR $^{\circledR}$ Green One-Step qRT-PCR Kit according to manufacturer's instructions.

2. Reaction conditions are as follows: a cDNA synthesis step at $55^{\circ} \mathrm{C}$ for $5 \mathrm{~min}$ and $95^{\circ} \mathrm{C}$ for $5 \mathrm{~min}$ and 40 cycles of $95^{\circ} \mathrm{C}$ for $15 \mathrm{~s}, 60^{\circ} \mathrm{C}$ for $30 \mathrm{~s}$, and $40^{\circ} \mathrm{C}$ for $1 \mathrm{~min}$, followed by a melting curve to confirm product specificity.

3 . Before assessment of target genes, determine reaction efficiencies of each primer set. Prepare fivefold serial dilution of total RNA and generate a standard curve with slope that defines primer efficiency. 
Immunofluorescence

3.4.2 Chondrogenic Differentiation
4. The efficiency of the reaction can be calculated by the following equation: $\mathrm{Eff}=10^{(-1 / \text { slope })}-1$. The efficiency of the PCR should be $90-110 \%$.

5. After determining primer efficiencies, perform gene expression analysis using different primers corresponding to different target genes.

6. Normalize resulting gene expression data to the expression level of a housekeeping gene.

1. At predetermined time intervals (1, 14, and 28 days) discard the differentiation medium from the wells.

2. In the fume hood, fix the cells with $4 \%$ paraformaldehyde in PBS for $15 \mathrm{~min}$.

3. Rinse three times with PBS.

4. Permeabilize cells with $0.1 \%$ Triton X-100 in PBS for 10-12 $\mathrm{min}$.

5. Rinse three times with PBS.

6. Block the cells with $1 \%$ BSA solution $(0.05 \%$ Tween $)$ for $2 \mathrm{~h}$ at room temperature.

7. Rinse three times with PBS.

8. Dilute primary antibodies in an appropriate concentration in blocking solution (see Note 7 ).

9. Add primary antibody in blocking solution at $150 \mu \mathrm{L} /$ well concentration. Incubate for $2 \mathrm{~h}$ at room temperature or overnight at $4^{\circ} \mathrm{C}$.

10. Rinse three times with PBS.

11. Add secondary antibody in blocking solution at $150 \mu \mathrm{L} /$ well concentration. Incubate for $\mathrm{l} h$ at room temperature. Keep the samples away from light.

12. Rinse three times with PBS.

13. To stain nucleus, add To-PRO in PBS (1:1,000 dilution) at $150 \mu \mathrm{L} /$ well concentration and incubate for $15 \mathrm{~min}$.

14. Rinse three times with PBS.

15. Mount on slides by using mounting media.

In the presence of TGF $\beta 1$ and small molecules such as insulin, dexamethasone MSCs undergo chondrogenic differentiation gaining chondrogenic morphology and producing cartilage-specific extracellular matrix molecules.

For this purpose, seed MSCs in growth medium (DMEMGlutamax $/ 10 \% \mathrm{FBS} / 1 \%$ penicillin) to the peptide nanofiber-coated wells at $5 \times 10^{4}$ cells $/ \mathrm{cm}^{2}$ density. After $24 \mathrm{~h}$ of incubation, 
Safranin-0 Staining

exchange the growth medium with chondrogenic medium as described in Section 2.

Safranin-O staining is used to show spatial organization of sulfated glycosaminoglycans. It is a cationic dye that binds to tissue glycosaminoglycans. The intensity of staining is proportional to the amount of glycosaminoglycans.

1. Remove the medium and wash cells with pre-warmed PBS.

2. Fix the cells with $4 \%$ PFA for 15 min followed by washing three times with PBS at room temperature.

3. In order to eliminate nonspecific binding, treat cells on scaffolds with $2 \% \mathrm{BSA} / \mathrm{PBS}$ for $30 \mathrm{~min}$.

4. Treat cells with $0.1 \%(\mathrm{w} / \mathrm{v})$ Safranin-O in $0.1 \%(\mathrm{v} / \mathrm{v})$ in acetic acid for $5 \mathrm{~min}$ at room temperature.

5. Wash cells with $0.1 \%$ acetic acid extensively.

Glycosaminoglycan Assay

DMMB assay is one of the accepted protocols for rapid quantification of sulfated glycosaminoglycans in tissue.

1. Remove the medium and wash cells with pre-warmed PBS.

2. Add $500 \mu \mathrm{L}$ papain solution on cells and wait for $5 \mathrm{~min}$ at $\mathrm{RT}$.

3 . Then collect cells after extensive pipetting into $1.5 \mathrm{~mL}$ Eppendorf tubes. Seal caps of tubes with parafilm.

4. Place the tubes on a hot plate at $65^{\circ} \mathrm{C}$ for $16-18 \mathrm{~h}$. The digests are used for both sulfated glycosaminoglycan quantitation by DMMB assay and DNA quantitation. Total DNA content will be used to normalize sulfated glycosaminoglycan content.

5. Quick spin Eppendorf tubes after 16-18 h. You can store papain digests in a $-20^{\circ} \mathrm{C}$ freezer. In order to increase the total DNA extracted from tissue, apply repeated freeze-thaw cycle.

6. Determine total DNA per experimental group by using Qubit dsDNA-HS quantitation kit according to manufacturer's instructions.

7. For DMMB assay, prepare serial dilutions of chondroitin sulfate standards in papain to generate a standard curve (Table 1).

8. Then aliquot $50 \mu \mathrm{L}$ of sample, controls, and standards in a clear bottom 96-well plate.

9. Add $100 \mu \mathrm{L}$ of DMMB dye solution on each well using a multichannel pipette.

10. Read optical density of samples at 590 and $530 \mathrm{~nm}$ values. Subtract the absorbance values of cell-free control groups from the absorbance values of experimental groups. 


\section{Table 1}

Volumes for chondroitin sulfate standard curve

\begin{tabular}{|lll}
\hline $\begin{array}{l}\text { Concentration of CS } \\
\left(\mu \mathrm{mL}^{-1}\right)\end{array}$ & $\begin{array}{l}\text { Volume of } \mathbf{1} \mathbf{~ m g ~ m L}^{-\mathbf{1}} \\
\mathrm{CS}(\boldsymbol{\mu L})\end{array}$ & $\begin{array}{l}\text { Volume of papain } \\
(\boldsymbol{\mu L})\end{array}$ \\
\hline 0 & 0 & 1,000 \\
\hline 5 & 5 & 995 \\
\hline 10 & 10 & 990 \\
\hline 15 & 15 & 985 \\
\hline 20 & 20 & 980 \\
\hline 25 & 25 & 975 \\
\hline 30 & 30 & 970 \\
\hline 35 & 35 & 965 \\
\hline
\end{tabular}

\section{Notes}

1. In our laboratory, we utilize MSCs from different origins like human, rat, and mouse. We have observed that using stem cells between passage 4 and 10 gives the most reliable and reproducible results.

2. Papain enzyme and cysteine are highly unstable. For this reason prepare Cys/PBE buffer and papain solution fresh and sterile.

3. DMMB dye solution is stable for 3 months. Check optical density and discard if it decreases appreciably.

4. Mechanical properties and ligand density of peptide gels can be tuned by their concentration. For this reason, molarity and volume of peptide solutions can be changed depending on the purpose of the study.

5. Alternatively, PBS and HEPES buffer can also be used to dissolve peptides. Depending on the sequence of each peptide and $\mathrm{pKa}$, adjust $\mathrm{pH}$ to 7.4 by using $1 \mathrm{M} \mathrm{NaOH}$ or $1 \mathrm{M} \mathrm{HCl}$.

6. Because xylene dissolves plastics, transfer $3 \mathrm{D}$ constructs from TCP to glass dishes before xylene changes.

7. Carry out the immunocytochemistry protocol without adding primary antibody to detect nonspecific binding of secondary antibodies. 


\section{References}

1. da Silva Meirelles L, Caplan A, Nardi NB (2008) In search of the in vivo identity of mesenchymal stem cells. Stem Cells 26:2287-2299

2. Crisan M, Yap S, Casteilla L et al (2008) A perivascular origin for mesenchymal stem cells in multiple human organs. Cell Stem Cell 3:301-313

3. Saha K, Pollock JF, Schaffer DV, Healy KE (2007) Designing synthetic materials to control stem cell phenotype. Curr Opin Chem Biol 11:381-387

4. Toksöz S, Guler MO (2009) Self-assembled peptidic nanostructures. Nano Today 4:458-469

5. Guler MO, Hsu L, Soukasene S, Harrington DA, Hulvat JF, Stupp SI (2006) Presentation of RGDS epitopes on self-assembled nanofibers of branched peptide amphiphiles. Biomacromolecules 7:1855-1863

6. Ceylan H, Tekinay AB, Guler MO (2011) Selective adhesion and growth of vascular endothelial cells on bioactive peptide nanofiber functionalized stainless steel surface. Biomaterials 32:8797-8805

7. Ceylan H, Kocabey S, Tekinay AB, Guler MO (2012) Surface-adhesive and osteogenic selfassembled peptide nanofibers for bioinspired functionalization of titanium surfaces. Soft Matter 8:3929-3937
8. Mammadov B, Mammadov R, Guler MO, Tekinay AB (2012) Cooperative effect of heparan sulfate and laminin mimetic peptide nanofibers on the promotion of neurite outgrowth. Acta Biomater 8:2077-2086

9. Anderson JM, Kushwaha M, Tambralli A, Bellis SL, Camata RP, Jun H-W (2009) Osteogenic differentiation of human mesenchymal stem cells directed by extracellular matrixmimicking ligands in a biomimetic selfassembled peptide amphiphile nanomatrix. Biomacromolecules 10:2935-2944

10. Mata A, Palmer L, Tejeda-Montes E, Stupp SI (2012) Design of biomolecules for nanoengineered biomaterials for regenerative medicine. Methods Mol Biol 811:39-49

11. Dagdas YS, Tombuloglu A, Tekinay AB, Dana A, Guler MO (2011) Interfiber interactions alter the stiffness of gels formed by supramolecular self-assembled nanofibers. Soft Matter 7:3524-3532

12. Mammadov R, Tekinay AB, Dana A, Guler MO (2012) Microscopic characterization of peptide nanostructures. Micron 43:69-84

13. Niece KL, Hartgerink JD, Donners JJJM, Stupp SI (2003) Self-assembly combining two bioactive peptide-amphiphile molecules into nanofibers by electrostatic attraction. J Am Chem Soc 125:7146-7147 